Bond University

Research Repository

\title{
"It's Like Standing on a Beach, Holding Your Children's Hands, and Having a Tsunami Just Coming Towards You": Intimate Partner Violence and "Expert" Assessments in Australian Family Law
}

Rathus, Zoe; Jeffries, Samantha; Menih, Helena; Field, Rachael M

\section{Published in:}

Victims and Offenders

DOI:

10.1080/15564886.2019.1580646

\section{Licence:}

Other

Link to output in Bond University research repository.

Recommended citation(APA):

Rathus, Z., Jeffries, S., Menih, H., \& Field, R. M. (2019). "It's Like Standing on a Beach, Holding Your Children's Hands, and Having a Tsunami Just Coming Towards You": Intimate Partner Violence and "Expert" Assessments in Australian Family Law. Victims and Offenders, 14(4), 408-440.

https://doi.org/10.1080/15564886.2019.1580646

\section{General rights}

Copyright and moral rights for the publications made accessible in the public portal are retained by the authors and/or other copyright owners and it is a condition of accessing publications that users recognise and abide by the legal requirements associated with these rights.

For more information, or if you believe that this document breaches copyright, please contact the Bond University research repository coordinator. 


\title{
“It's Like Standing on a Beach, Holding Your Children's Hands and Having a Tsunami \\ Just Coming Towards You": Intimate Partner Violence and Expert Assessments in \\ Australian Family Law"
}

\begin{abstract}
The ways in which post-separation parenting disputes are managed has undergone significant change in Australia since the Family Law Act (Cth) was first enacted in 1975. The best interests of children have always been paramount in children's cases and over the last twenty years, this concept has been legislatively shaped to include on-going beneficial postseparation parental relationships and protection from harm. A critical piece of evidence to inform a Family Court's decision-making in such matters is a family report, which is an expert assessment compiled by a social science professional. In this article we report findings from an Australian based qualitative study exploring the experiences of family report assessment practice from the perspective of victim mothers who have separated from men who perpetrate intimate partner violence. The article concludes that reforms are necessary to improve the practice and procedure of family report writing in Australia. Such reforms should ensure that the lived experience of victims of intimate partner violence is validated, assessment processes have victim efficacy, and the outcomes of such reports do not put women and their children at on-going risk of harm.
\end{abstract}

\section{PART I: Introduction}

Cases involving families where there are allegations of intimate partner violence (IPV) ${ }^{1}$ constitute a significant part of family court caseloads in Australia. IPV can be defined as 'any

\footnotetext{
${ }^{1}$ We have mainly used the term intimate partner violence in this article because our focus was on violence against women in heterosexual relationships. In Australia the relevant legislation, the Family Law Act 1975 (Cth), uses the term 'family violence' but that encompasses a broader spectrum of violence than we examined.
} 
behaviour by a man or a woman within an intimate relationship (including current or past marriages, domestic partnerships, familial relations, or people who share accommodation) that causes physical, sexual or psychological harm to those in the relationship' (Our Watch, 2015, p. 62). IPV is the most common form of violence against women (WHO, 2010).

A recent Australian Parliamentary Report stated that 50\% of cases in the Family Court of Australia and $70 \%$ of cases in the Federal Circuit Court of Australia $^{2}$ involve allegations of violence (House of Representatives Standing Committee on Social Policy and Legal Affairs, 2017 p. 2; Sifris and Parker, 2014, p. 5). A critical piece of evidence frequently obtained in these cases is a family report, which is prepared by a family consultant or family report writer $(\mathrm{FRW})^{3}$ who is usually a social worker or psychologist. A family report is a social science assessment of the family that considers a range of matters relating to the 'best interests of children'. ${ }^{4}$ There may be specific issues the FRW is asked to examine by the judge hearing the case, or the Independent Children's Lawyer (ICL). ${ }^{5}$

IPV is experienced acutely by children and parental separation often increases the frequency and intensity of such violence (Buckley \& Whelan, 2008; Callaghan, Alexander, Sixsmith \& Fellin, 2018; Gillindger \& Goddard, 2007; Holt, Pence, Davis \& Beardslee, 2012; Radford \& Hester, 2006). A recent report showed that family reports are increasingly being obtained in cases involving allegations of IPV (Kaspiew el al., 2015b, p. 51). This suggests that FRWs have a critical role to play in how the family law system deals with IPV allegations in parenting cases. However, Australian research specifically on this intersection of family reports

\footnotetext{
However, when we are quoting from the interview participant mothers we have used whatever language they used - which was usually 'domestic violence'.

${ }^{2}$ The Family Courts of Australia and the Federal Circuit of Australia will be referred to as the 'family courts' in this article. They both operate at federal level but the Family Court is the superior court.

${ }^{3}$ Although under the FLA certain professionals who are commissioned to prepare family reports are called 'family consultants' (See Family Law Act 1975 (Cth) s 11A and s 11B), we have used the term FRWs because there is now a range of social scientists who prepare family reports. Those employed at the family courts are 'family consultants' as defined, but others are not.

${ }^{4}$ A statutory definition of 'best interests of children' is set out in the FLA 1975 (Cth) s 60CC(2) and (3).

${ }^{5}$ Independent Children's Lawyers are appointed to complex cases judges under s 68L of the FLA.
} 
and intimate family violence is limited to five studies with other research touching on the topic (Hemphill, 2013; Jeffries et al., 2016; Kaspiew et al., 2015a; Kaspiew et al., 2015b; Moloney et al., 2007; Shea Hart, 2011). In this article we report findings from an Australian based study exploring the experiences of FRW practice from the perspective of victim mothers ${ }^{6}$ who have separated from men who perpetrate IPV. The study used in-depth interviews with the mothers which were qualitatively analysed using triangulated thematic analysis. As far as we know the study is the first in Australia to look at FRW practice from the perspective of IPV victims, although a much an earlier study considered the perspectives of children and their protective parents in the Western Australian family courts (Hay, 2003).

Australian family law favours shared parenting post-separation arrangements in terms of both physical care and decision-making, although it also emphasises protection from IPV and the protection of children from physical, psychological and emotional harm. Australian and international research shows that significant periods of contact are frequently awarded to domestically violent men through family courts (Bagshaw et al., 2010; Chisholm, 2009; Coy, Scott \& Tweedale, 2012; Dragiewicz, 2014; Easteal \& Grey, 2013; Holt, 2011; Jeffries, 2016; Kaspiew, Gray, Weston, Moloney, Hand \& Qu, 2009; Meier, 2003; Naughton, O’Donnell, Greenwood \& Muldoon, 2015; Rathus, 2010; Saunders, 2007).

In an adversarial legal system such as Australia's, judges make their decisions based on the evidence presented by the parties (Fields, 2008). A critical piece of that evidence in parenting cases is the family report. Therefore, it is concerning that a 2017 Parliamentary Committee noted that it had received numerous submissions about the poor quality of some family reports and the failure of many actors in the family law system, including FRWs, to deal

\footnotetext{
${ }^{6}$ We have chosen to use the word 'victim' in this article, because the mothers were generally quite recently separated and were still in, or dealing with, the family law system. They were not yet survivors.
} 
appropriately with women and children who had experienced IPV (House of Representatives Standing Committee on Social Policy and Legal Affairs, 2017).

This article is structured as follows. Part II provides background to the empirical aspect of our research, discussing relevant literature on IPV, outlining the family law context in Australia and briefly examining some of the limited available literature on family report writing. ${ }^{7}$ Part III explains the research methodology of the study, and Part IV reports our findings. Part V synthesises our key conclusions from the data and offers some tentative recommendations for reform of FRW practice and procedure.

\section{PART II: A Snapshot of IPV Research}

\section{Coercive control and violence}

Over the last half century our understanding of violence in intimate relationships has shifted from a focus on physical safety to include a more nuanced appreciation of IPV including the damage and impact of non-physical abuse on spousal victims, usually women, and their children. The Australian National Council to Reduce Violence against Women and their Children (NCRVWC) (2009) has described the range of abusive behaviours associated with IPV as including: emotional, verbal, social, economic, psychological, spiritual, physical and sexual violence. Some victims of IPV experience physical, sexual and more overt types of violence, while for others the violence is mainly psychological, emotional and social. Indeed, survivors of IPV have reported that the day-to-day experience of more subtle manifestations of violence - such as constant criticism, financial abuse, social isolation and threats - can be just as damaging (and sometimes more damaging) than physical assaults (Bagshaw, Chung, Couch, Lilburn, \& Wadham, 2000). Perpetrators often combine various forms of violence to create an atmosphere of coercive control of the victim (Stark, 2007). The women we interviewed

\footnotetext{
${ }^{7}$ Or 'custody evaluations' as they are called in the USA.
} 
described having experienced all forms of violence identified by the NCRVWC and explained how they merged into a pattern of on-going controlling conduct.

Perpetrators of violence also understand the power of threats of violence and employ threats to keep their victim on edge. Threats of physical violence, for example, can extend the fear of actual physical violence over days on which physical violence is not perpetrated against the victim. Rowan (1985, p. 27) has explained how the "package" of abuse that comes with IPV is "accompanied by daily threats" regarding the risks of leaving - losing the house and children - and brainwashing to "create in [the woman] a belief that she is the cause of the violence...". Threats can be employed as an insidious tactic to keep women in violent relationships.

Humiliation, degradation and emotional unkindness are also strategies used by perpetrators to establish their superiority through the disintegration of a victim's self-respect, sense of self-worth and esteem. The enforcement of trivial demands can result in victims feeling that their everyday lives are being micromanaged, crushing their spirit and leaving "little space for personhood to breathe" (Stark, 2007, p. 274).

Further, while many male perpetrators do not actively engage in parenting tasks when the relationship is intact, they often threaten to remove the children from the mothers: to take them away physically themselves or to have them removed from the mother through family law proceedings or by child welfare authorities (Rendell, 2002; Australian Law Reform Commission, 2018). The constant denigration of a woman's mothering skills gives credibility to these threats in her mind. In addition, after separation, many perpetrators skilfully use such tactics to engage the children in their ongoing campaign of control and intimidation against the mother (Rendell, Lynch \& Rathus, 2000).

These factors partly explain why some women have difficulty articulating the abuse they have experienced or are experiencing, its ongoing impact on their lives and their sense of 
anxiety for the safety of the children when they are with their father. As a consequence, a victim mother's concern to protect her children from harm perpetrated by the father may seem disproportionate, oppositional and an over-reaction. However, research shows that the negative impacts of the experience of coercive controlling behaviour can be significant and long-lasting (Bagshaw et al., 2000; McKinnon, 2008).

IPV is a complex societal problem. Relationships in which IPV is present are multidimensional, and so are the actors. Perpetrators are not always violent and victims are not always cowering - thus complicating both the public presentation and private inhabiting of the relationship. It has long been understood that domestically abusive men can be charming outside the home (Rowan, 1985) and this can create serious problems for women victims seeking to confide in family and friends who have only seen the perpetrator performing in charming mode. Perpetrators of IPV can also be charming, romantic and intensely loving inside the relationship, particularly at the beginning. For example, the IPV literature describes a phenomenon known as 'love bombing' - a common tactic used to groom would-be victims in the early days of a relationship (Hayes \& Jeffries, 2015, p. 38; Hennessy, 2012, p. 77). Happy experiences or expressions of passionate love can later manifest as control, social isolation and sexual jealousy.

Sexual violence is often a part of IPV. It manifests in many ways including the use of "high force" physical violence, "non-physical tactics of manipulation", "non-consensual dominating or humiliating tactics" and forcing unwanted sexual acts (Cox, 2015, p. 11). Sexual violence also plays a role in the exercise of control. Women often remain silent because children are present (in the same room or bed) and resisting will almost certainly bring them into the violence, at least as aural witnesses (that is, hearing but not seeing the violence being perpetrated). Women are also afraid that failure to provide sex might bring on a nasty mood in 
which the children become victims - activating the mother's protective role and shifting the sense of responsibility for the violence away from the abuser to the mother.

\section{Perpetrators' parenting capacity}

The abusive behaviours of perpetrators generally call into question their paternal parenting capacity, but this is not always recognised or considered, particularly in legal contexts. As the President of the Family Division of the English Court of Appeal, Dame Elizabeth Butler-Sloss, said in 2000: "It may not necessarily be widely appreciated that violence to a partner involves a significant failure in parenting - failure to protect the child's carer and failure to protect the child emotionally" (Re L (A Child) (Contact: Domestic violence) and Others [2001] Fam 260, 272-3).

Research highlights that, in contrast to non-abusive men, domestically violent fathers are often: poor role models (for example, exhibiting patriarchal norms, deviant and/or criminal behaviour to their children); overly rigid, authoritarian or coercive in their parenting style; lacking in empathy, selfish, emotionally manipulative and possessive of their children; and possess an inflated sense of entitlement which can result in parent/child role reversal (Bancroft et al., 2012; Holt, 2015; Jaffe, Lemon \& Poisson, 2003; Meier, 2003; Peled, 2000; Pence, Davis, Hardesty, Haselschwerdt \& Johnson, 2012; Radford \& Hester, 2006; Stark, 2009; Kaspiew et al, 2017). Such attitudes and behaviours are heightened during post-separation contact where perpetrators are afforded longer periods alone with their children.

\section{Relationship dissolution and pre-court post-separation parenting}

Children living with post-separation IPV are often especially distressed because child contact can become the avenue for perpetrator fathers to intimidate and control their former intimate partners (Harrison, 2008; Radford \& Hester, 2006; Stark, 2007; Thiara \& Harrison, 
2016). In addition to children witnessing their fathers perpetrating violence against their mothers at 'hand-overs', ${ }^{8}$ children are often habitually used and engaged in perpetrators' extended campaigns of control and intimidation against mothers (Rendell et al., 2000). This manifests in a number of different ways. Children can be directly abused, neglected or endangered during contact visits to incite fear in victim mothers (Bancroft et al., 2012; Radford \& Hester, 2006; Thiara \& Harrison, 2016). Other examples of such post-separation abuse include: requiring the children to monitor and report on their mother's lives; involving children in discussions about harming their mother; returning the children dirty, unfed or emotionally distraught; and using child contact litigation (or threats of) to intimidate and harass the mother. Thiara and Humphreys (2017) call the infiltration of the post-separation lives of victim mothers and children an 'absent presence' on the part of perpetrators.

The short, medium and long-term impacts of IPV on children are now well understood and include: difficulties with school and later educational aspirations; difficulties establishing social groups; for some boys, manifestations of anger which may lead to involvement in the juvenile justice system; for some girls, internalising of anger and distress which may lead to depression and potential self-harm; difficulties establishing trusting adult relationships; an inability to maintain steady employment; and for some men who witnessed the perpetration of violence against their mothers, there is an increased likelihood that they will subsequently perpetrate violence on their partners (Abbassi \& Aslinia, 2010; Ehrensaft, Cohen, Brown, Smailes, Chen \& Johnson, 2003; Thomsen, Crouch, May, Gold, \& Milner, 2005; Saunders, 2007; Gillindger \& Goddard, 2007).

When courts order on-going contact between children and their abusive fathers, mothers and their children are not extended an opportunity to heal. Rather victims continue to live with the trauma of IPV (Radford \& Hester, 2006). Studies show that contact with a

\footnotetext{
${ }^{8}$ Parental exchange of children at designated drop off and pick up points.
} 
domestically violent parent is a generally negative experience because, as observed by Radford and Hester (2006, p. 95): "everything that happens to children living in families where there is IPV also happens after separation, and sometimes the incidents get worse". However, if mothers are hesitant or reluctant to send their children to fathers who have been abusive to themselves or the children, in the family law system they are often accused of alienating the children from their fathers (Davis, O’Sullivan, Susser \& Fields, 2010).

\section{Family Reports}

In Australia, family reports are prepared by social scientists who are usually social workers or psychologists. A family report provides independent expert evidence about family dynamics and guidance around how children's best interests might be served post-separation (Cashmore \& Parkinson, 2009; Easteal \& Grey, 2013; Field et al., 2016). They are often the only social science evidence available in parenting matters, and therefore need to provide the best evidence possible to enable decisions that are in the best interests of children, and that work to protect children from IPV.

There is a range of professionals who prepare documents which will be labelled 'family reports' and there are a number of ways such a report may be commissioned in a case. It may be ordered by the judge, ${ }^{9}$ commissioned by the ICL or arranged by the parents or other parties to the dispute. It may be undertaken by a professional employed at a family court, an appropriately qualified staff member at Legal Aid Commissions, ${ }^{10}$ or by a private practitioner who may, or may not, hold a special appointment to prepare reports from the Chief Executive Officer of the Family Court of Australia or Federal Circuit Court of Australia. ${ }^{11}$ A common

\footnotetext{
${ }^{9}$ FLA s $62 \mathrm{G}$.

${ }^{10}$ Legal Aid in Australia is legal assistance provided by the government. Each state and territory has its own Legal Aid Commission, which is responsible for administering Legal Aid. There are Legal Aid offices in cities, suburbs and towns across Australia (see https://www.australia.gov.au/information-and-services/public-safetyand-law/legal-aid).

${ }^{11}$ See Family Law Regulations 1984 (Cth), reg 7.
} 
feature of FWRs is that they are deemed to be independent witnesses who have not been hired by any one party. However, the qualifications of FRWs, their experience, on-going training, access to resources, supervision arrangements and practice frameworks are profoundly variable.

\section{Prior Research - IPV and Family Reports/Expert Assessments}

International research suggests that the experts who write family reports sometimes focus on physical violence and do not pay adequate attention to coercively controlling violence (Saunders et al, 2012; Pence et al, 2012). This points to a need for improved assessment practices as well as deeper understandings and/or further training about the nature and impact of coercive control (Walker, 2016). Assessments that are made for the purpose of a family report are often made under tight time constraints, with reliance on a relatively limited range of information sources (for example, parents and children are interviewed for short periods of time, and extended family, teachers, psychologists, child protection workers, police and others who have a knowledge of the family are often not consulted) (Haselschwerdt et al., 2011; Saunders et al., 2012).

In Australia initial family reports are often prepared reasonably soon after separation. Violence may still be continuing and the mothers face assessment when they may not have had time to process their experience of violence nor feel completely safe in a new space. Australian research specifically focussed on FRWs and their treatment of IPV is limited to five dedicated studies and two notations in larger research projects (Hemphill, 2013; Jeffries et al., 2016; Kaspiew et al., 2015a; Kaspiew et al., 2015b; Moloney et al., 2007; Shea Hart, 2011). Two of the dedicated studies occurred before the 2012 family violence reforms to the FLA.

The Moloney et al. (2007) study found that commonly, views about specific allegations of IPV do not tend to be expressed in family reports. Analyses of evidentiary material about 
IPV in family reports ( $n=300$ file cases between 2002 and 2003) revealed that "of all allegations raised, no more than $10 \%$ were fully or partially corroborated" by a family report, and "no more than 2\% were fully or partially discredited” (Moloney et al., 2007, p. 91).

Shea Hart's (2011) qualitative analyses of Australian family court judgments between 1991 and $2001(n=20)$, found that the context of violence within the family tended to be minimised by FRWs. IPV was frequently reconstituted as mutual parental 'conflict', and it was this, rather than exposure to what were often extreme acts of IPV, that was perceived to be impacting adversely on the children. Mothers were not interpreted as being protective but were described as 'hostile' and were situated within a strong discourse of parental alienation criticised for interfering, destabilising and sabotaging relationships between perpetrators and their children. Rather than prioritising child safety and the protection of children from harm, the family report assessments referred to in the judgments reviewed by Shea Hart (2011) tended to construct the child's best interests in terms of maintaining the perpetrator/child relationship. There are limits to the conclusions that can be drawn from this research given its small scale, the secondary referencing of the family reports through judgments and the fact that the research took place prior to the 2012 reforms to the FLA concerning family violence. However, Shea Hart's (2011) findings are supported by more rigorous international explorations of this issue (see for example, Saunders, 2007; Saunders et al., 2012), as well as more recent Australian studies (Jeffries et al., 2016).

More recently, Hemphill's (2013) survey of Australian family reports $(\mathrm{n}=58)$ and analysis of family reports $(n=200)$ - one set on either side of the 2012 family violence amendments - suggested that FRWs had difficulty differentiating coercive control from other types of violence (for example, mutual abuse). The survey component of this research indicated FRWs had become more knowledgeable about IPV post the 2012 reforms; however, analyses 
of assessment documents revealed a disjuncture between reported understandings, assessments and recommendations - suggesting very little had in fact changed.

As part of a larger evaluation of the family law system post-2012, the Australian Institute of Family Studies evaluation showed family reports were more likely to be ordered in cases involving IPV post-reforms (33\% cf. 53\%) and there was an increase in "explicit discussion of risk assessment" (22\% cf. 31\%) by FRWs (Kaspiew et al., 2015b, p. 65). However, a survey of judges and lawyers indicated there was "some unevenness" when they were asked whether FRWs "had provided recommendations that addressed the implications of information about family violence, child abuse and child safety concerns since the family violence reforms" (Kaspiew et al., 2015a, p. 43).

Jeffries et al.'s (2016) focus group study explored the practices of FRWs in Queensland (Australia) from the perspective of those providing legal and social support to victims of IPV. Participants overwhelmingly expressed that FRWs had a tendency to invalidate IPV and prioritise the maintenance of perpetrators' relationships with their children. Many findings reflected the literature already canvassed, but some other themes also emerged, including:

- presenting IPV as extraneous to perpetrators' parenting;

- recognising the impact of coercive control on maternal parenting but only in terms of the risk those victims posed to their children;

- reconstituting IPV as something else i.e. 'not that serious, 'episodic', 'only parental conflict', and/or an act from the past that victims needed to 'get over'; and

- giving credibility to children's views that reflected the discourse of maintaining a relationship with their father while dismissing negative views as being fanned by their mothers.

The participants in Jeffries et al.'s (2016) research took the view that the invalidation of IPV in family reports resulted from a lack of FRW training and thus expertise in IPV, 
alongside judicial pressure for the maintenance of children's relationships with both parents as well as assessment processes which lacked efficacy. Recommendations for equal shared parental responsibility (ESPR) and for children to spend significant unsupervised time with the perpetrator were described as commonly occurring in matters involving IPV. The implementation of such recommendations in family reports was seen as placing mothers and their children in a situation of ongoing risk of harm, as family reports have a significant determinant impact on final parenting arrangements. Further, the participants reported little change in family report writing practice since the 2012 family violence amendments to the FLA.

\section{PART III: Methodology}

The study reported in this article is the first in Australia to explore the family report writing process from the perspective of mothers who have survived IPV. Our research highlights mothers' voices and their lived experience of the family report assessment process in a way that has not been done before in the Australian scholarship.

\section{Participants}

Ten in-depth interviews were undertaken in south-east Queensland (Australia) with women who had survived IPV and were, or had been, involved in family law proceedings. The participants were recruited through our collaborator on the project, Women's Legal Service Queensland, as well as through other IPV organisations and legal service providers and through the professional networks of the researchers. The women ranged in age from 28 to 46, with most in their 30s and 40s. Six were born in Australia and the other four were born in the UK and Europe. The numbers of children ranged from one to five, with a number of step-children included as well (totalling 20 children directly of the relationships, from infants to teenagers at 
the time of parental separation). Most of the fathers were Australian-born, although at least two were born in other English-speaking countries. The shortest relationship was about two years and the longest eleven.

\section{Method}

The nature of vulnerable populations (such as survivors of IPV) requires research methods used in such contexts to be as flexible, sensitive and non-intrusive as possible (Liamputtong \& Ezzy 2005). To achieve a comprehensive insight into the experiences of family report writing processes, the most appropriate method was interviewing. For in person in-depth interviews, Thompson (1978) outlines useful features as including: interest and respect for people as individuals, flexibility in responding to them and an ability to show understanding and sympathy for others' points of view. It was considered that interviews would allow for an exploration of the participants' perspectives on living with IPV, as well as how IPV impacted their lived experience of the family law system. The researchers also took the view that interviews would enable an understanding and positive relationship to be established between the interviewer and the interviewee (Schensul, Schensul \& LeCompte, 1999).

At the beginning of each interview the researchers explained the aim of the study, as well as the confidential, anonymous and voluntary nature of participation. Written consent to participate was provided by each interviewee. Anonymity was further protected by assigning each woman a pseudonym, changing the names of any partners or children mentioned and altering minor details of their stories that had no bearing on the research purpose. The interviews, which ran from one to three hours, provided a space for discussion of the following five broad topic areas:

1. Relationship history including experiences of IPV and other family violence.

2. History of family law proceedings. 
3. Observations about FRWs responses to IPV.

4. The family report assessment process including observations regarding approaches and impacts on victim mothers and their children.

5. Family report discussion and recommendations including observations about how IPV is addressed and how recommendations impact on final parenting arrangements.

All interviews were recorded and later transcribed; the verbatim de-identified transcripts were then thematically analysed. To aid our analysis, we used a computer-assisted qualitative data analysis program NVivo. This program works on a code-and-retrieve theme basis. The theme coding process was also triangulated across project team members and crosschecked. When probing for themes we searched for repetitions, similarities, differences, metaphors, and analogies (Ryan \& Bernard, 2003). During this process, we reflected on the codes in order to gain a sense of continuity and linkage between them.

There are various debates regarding qualitative research and generalisability. Denzin and Lincoln (1995) have argued that generalisations are not particularly desirable or suitable for qualitative research but Bryman (2012) more recently noted that qualitative research provides rich explanations that enable conveyability, and consequently, the ability to generalise to theories on a broader scale. Similarly, Payne and Williams (2005) suggest that qualitative research can facilitate generalisations; yet, these generalisations tend to differ from those made from a statistically-representative sample. We also note that qualitative research brings insights not accessible through quantitative data and thus is useful for highlighting issues for further research. The key issue here is for the researchers to demonstrate that the research undertaken generated relevant and substantial knowledge.

Because our sample consisted of ten women in one geographic location, it cannot be considered statistically representative of women undergoing the FRW process throughout Australia and empirical generalisations cannot be made. Nevertheless, the data gathered was 
consistent with the extant international and Australian research, allowing some tentative findings to be made (see Jeffries, et al., 2016; Field et al., 2016 for a comprehensive discussion of the international and national literature).

\section{Ethics}

The research team received ethics approvals from the relevant universities' ethics committees before commencing the project. ${ }^{12}$ However, it was never possible to obtain approval to read the actual family reports of the women as that required additional consideration by the ethics committees of the Family Court of Australia and Federal Circuit Court of Australia. There were obstacles in this regard: a section of the FLA generally restricts publication of any identifying family law material; ${ }^{13}$ the reports were not the property of the women; many people's intimate or personal details were revealed in them and orders restricting their publication are often made. It was not always clear to us whether such an order existed in particular cases and we did not want to risk involving our participants in actions that could be considered contempt of court. Therefore, the reports themselves do not form part of our data. ${ }^{14}$

The women we interviewed were at different stages of their legal proceedings. Some had completed proceedings, others had not. Some of the women advised us of their final outcomes subsequent to the interviews. Because of these differences, and our lack of access to the actual reports, we are unable to report on all of the final recommendations made in the family reports, or the final orders made - whether by consent or judicial order. However, where the women were able to provide detail on these issues at the interviews, or subsequently, we have included details of these outcomes to provide as comprehensive a picture as possible.

\footnotetext{
${ }^{12}$ Griffith University and the Queensland University of Technology in Brisbane Australia.

${ }^{13}$ FLA s 121 - which arguably includes publication by the mother of the family report to the research team.

14 The research team has recommended to a current Inquiry into the family law system that consideration be given to legislative reform that would enable access to family law documents for bona fide research activities (Australian Law Reform Commission (2017-18) Review of the Family Law System).
} 


\section{PART IV: Findings}

To contextualise the data from our interviewees about the family report writing process, we start by revealing the early charm and "love-bombing" displayed by the men and report aspects of the IPV experienced by the participants pre and post separation. The narratives of the lived experience of the participants show how the pervasive perpetration of emotional, psychological and social abuse against mothers creates a sense of personal invasion that facilitates the abusers' control over their daily life and broader existence. Also described are the mothers' experiences of fathers' (lack of) parenting capacity, subsequent impacts on maternal parenting, relationship dissolution and post-separation parenting arrangements precourt process. Finally, we describe the women's perceptions of the family report writing process and the ways in which the practice and procedure of the family report assessment process can be improved.

\section{Early charm and 'love-bombing'}

The women described the initial stages of their relationship with their children's fathers as a "whirlwind" romance with a charming, romantic man who "swept them off [their] feet", promising love and much more. Belinda told us for example:

He swept me off my feet, by the way. In terms of spoiling me, my goodness. Anyway, he was writing this book with a friend of his and he said, I want to go to Europe and do research and write my book and you have to come with me. So yeah, he swept me off my feet. Took me to Europe and all this and then - we got engaged quite quickly. 
Jane was only 19 years old when she met her future husband who was in his early 30 s. He flew half way around the globe to romance her, promising her a better life in Australia, economic security and to always treat her with respect and dignity. She explained: He said, "You've got to give me a chance. I fell in love and if you stay in Russia, you know, even with your profession, you'll be forever on the little wage." And he said, "No man in [country] would treat you well... most [are] alcoholics... and they treat their wives bad. But I'll treat you beautifully. I will always respect you, I will never raise a hand on you and I'll never raise a voice on you and I will always respect you." I think when I heard all this saying, his look [older man] never mattered to me, I said I should give this man a chance.

Interviewees recounted how they now identify these early 'romantic' behaviours as warning signs. For example, Mary explained that in the initial days she interpreted her expartners incessant text messaging as a sign of love, but now understands this to be a 'red flag' for controlling behaviour:

So looking back now he would text easily 20 times a day and I thought that was great because I was like oh he cares about me, he's interested in what I'm doing, who I'm spending time with, all this stuff, but I know now that's an alarm bell but at the time I thought it was great - ringing me all hours of the day and night and texting and very interested in what I'm doing. I was so young and naïve.

\section{Coercive control, physical and sexual violence}


There were many forms of non-physical violent behaviours the men utilised to incite fear, anxiety, despair and subsequent compliance in the mothers. For the interviewees common behaviours included: verbal threats (such as threats to kill), threatening behaviour (for example, property destruction, self-harm, dangerous driving and other displays of intimidation and aggression), abuse of animals, use of children (for example, threats to take the children away, interrupted nurturing) and use of social institutions (such as threats to report to the Department of Child Safety, use family law or criminal proceedings to sever the mother/child relationship). Their partners would invade their personal space and privacy and monitor their every move, demanding that the women account for how they spend their time, and also stalking them. For instance, Bronwyn told us:

He called me on Skype every day [when he was overseas]. At least once. I mean to the extent that I had to be there for his call and I would get questioned if I wasn't. He had a friend here and he would keep tabs on me. He knew where I lived, where I was, dropped in unexpectedly, that kind of thing.

Jane's experience was similar:

He controls my phone, he knows every step of mine - he knows every message, every phone, everything, he knew everything.

Bronwyn explained how her husband would use the 'silent treatment' and facial expressions to communicate that she was under threat:

When he got angry, he didn't usually do something straight away. But you knew... his jaw would go tight. You could just see this kind of pulse thing. Sometimes it would be like a week later he would do something. 
He would do the silent treatment for a while usually. You would know. Sometimes he would act kind of like normal. But you would know. You could feel it and he would talk a certain way. So you'd wait for it to come.

Threats and intimidation regularly occurred when the children were present:

I remember - the thing about Tom is that he would be angry for days. You'd be walking on egg shells for days. It was - that was what was hard, was that the constant fear for days. I think the children very much so had to deal with that as well. (Ursula)

The women also recounted a number of different ways in which their spouses restricted their personal territory and autonomy including: economic abuse, isolation from family, friends and networks, enforcement of trivial demands and, often unpredictable, intrusion into private spaces. For example, Isabelle explained how her husband isolated her from support after the birth of their children:

So when I had babies, he wouldn't allow anyone to come around and help me in any way. He was very restrictive as to - it was all about his little world of church members and friends and family. I just got suffocated by it.

Criticism was often aimed at the parenting ability of the mother in order to undermine the mother-child relationship:

I was breastfeeding up until five and a half months...So every hour and a half I was feeding her. I got in trouble because I was feeding her too 
much.... I had the midwives come and do home visits and they said no, she's fine. Then after that he refused to be at home when they turned up. Then she was doing poos every day and then he got mad at me because she wasn't supposed to be pooing every day. (Donna)

The women recounted how their spouses frequently refused to take responsibility for household tasks (including child care) but would instruct them on how best to carry out their 'womanly duties'. Bronwyn explained:

One time he got me by the wrist and he took me into the kitchen and showed me where I had thrown away one of those blue and white Chux cloths. ${ }^{15}$ He demanded to know why I had thrown it out. I told him well I've cleaned the toilet with it. Then he gave me a lecture on how I should use the brush to clean the toilet. I'm telling him well no, and I find myself justifying how I clean the damn toilet. You know? I used to work in senior corporate jobs and fly around the world and I'm standing there justifying to this man why I threw away a Chux cloth.

Restricting personal territory and freedom is a pivotal tactic that abusive men use to deprive victims of support, making them dependent and quashing their self-identity. As noted by Jane, "he doesn't even allow you to even think for yourself to do things for yourself". A friend of Isabelle's commented on her loss of self-identity asking "what's happened to you? Your spark's gone... I said, [my husband] doesn't like it. So anything that was arty, or London girl, was completely squashed.

15 This is a brand of disposable dish cloth very commonly used in Australia. 
Many domestically violent men present very differently in public than they do in private. This can create confusion in victims because others may perceive the perpetrator as being the opposite of abusive. This two-sided persona was described by Isabelle as follows: I was going to the ... leaders in the church saying my husband's really abusive. He screams [at us] all the way to ... church and when he gets out of the car, he'll just run off and do his church activities... On the way home it would be the same stress. So he was like a Jekyll and Hyde.

The mothers reported their experience of physical abuse as taking the form of pushing, shoving, slapping, punching, kicking and strangulation. These behaviours intensified during pregnancy or post childbirth and frequently played out in front of the children. Fiona told us:

So at the end of June we're moving [house] and he's cracking the shits because I haven't got the highchair ready. I didn't wipe it down clean, whatever, for [Brooke] to have her dinner. Then he's there shaking me by the neck ... and Brooke's there screaming her head off. He's yelling at the top of his lungs and she's terrified and he wouldn't give her to me.

Bronwyn's partner was a karate expert who would use karate moves on her, sometimes hurting her but claiming it was either an accident or that he was just practising his karate and not meaning to hurt. There was a finding at the trial, which took place after the interviews, that Bronwyn's husband was narcissistic, although there were also mental health concerns for Bronwyn. The topic of diagnosed or suspected narcissism in the fathers arose in five of the ten interviews. ${ }^{16}$

\footnotetext{
${ }^{16}$ Some research suggests that male narcissists will behave with particular hostility towards heterosexual women (Keiller, 2010).
} 
Some women reported being coerced into performing sexual acts they were not comfortable with. Often this sexual abuse occurred whilst the women were pregnant and/or when their young children were in the room sleeping. Non-compliance with spousal sexual demands invariably resulted in negative consequences. Ursula explained how her partner's incessant sexual requirements persisted even when this caused her pain and their young son was sleeping in room:

It [sex] was either daily or every second - or twice a day. So when I had an IUD and it hurt, he still persisted and - even though it hurt. He did, even though Felix was in the bed. So you're talking a two, three year old. If I didn't...he'd be aggressive ... abusive, rages or manipulative or verbally belittling.

Donna also reported degrading sexual acts: [He] used to make me do sexual things I didn't want to do, like disgusting things.... He used to like anal sex and I hate it.... One time he actually hurt me so bad I ended up in tears. I ended up at the doctor. I told [him] I was hurt. I shouldn't have told him that because he kept trying to put it [in my anus]. Once he even peed in my mouth and that was just - yeah, that was disgusting and he laughed at me. Talia slept in our room and she was getting older. He didn't even care if she was awake or not. He used to wrap his hand around my throat and the further we got along in the relationship, it got tighter and tighter.

As will be discussed further, there was a general perception amongst the participants in this research that the FRWs did not fully understand the gravity of the sexual violence and its 
impact on them, or how the experience of it affected their attitude to the children spending time with their fathers.

\section{Parenting capacity of fathers}

Prior to separation most of the women described their abusers as disengaged parents, patriarchal men who saw childcare as women's work. For example, Narelle told us: He never wanted anything to do with the children before we separated... he would never look after them ... I wasn't even allowed to leave them with him for half an hour just to go down the supermarket and buy bread and milk, he literally abused me for three hours one day because I did.

Further, the women reported that the fathers engaged in a range of other problematic behaviours including: substance misuse, problematic gambling, sexual deviancy, fraud, and breach of IPV orders. Donna, for example, explained:

He used to leave his bong and bowl and that around and she [their nine month old daughter] used to get into it. A couple of times she nearly drank the bong water.... She's had buds in her mouth, foil in her mouth, cigarette butts in her mouth. His drug run was every Tuesday - probably still is. We all had to get in the car, me and the kids, as one kid didn't always have a seat belt in the back because you can't put four kids in the seat.

The men's parenting pre-separation was described as lacking in empathy and respect, and as being authoritarian, neglectful, irresponsible and abusive: 
I had Wendy with me and she was a tiny baby. He'd be telling her to sit up and sitting her on the table and she couldn't hold her head up.... My

friend was just speechless. I'd be trying to get her from him. He'd be like ordering her to sit up. I don't know how old she was, maybe a few weeks. He would be telling my friend about how clever he was because he was teaching her strength exercises. (Bronwyn)

\section{Relationship dissolution and pre-court post-separation parenting}

For every woman, the experience of IPV invariably led to the breakdown and dissolution of their intimate relationships. For some, there was a defining moment in which the coercive control escalated to such an extent that the fear of staying in the relationship transcended the fear of leaving it. Others connected with outside help (for example, IPV service providers, doctors, therapists, police and lawyers) and with support were able to escape. Some women were eventually worn down by the years of abuse and simply could not stand it anymore. All knew that leaving was dangerous. They were fearful not only for their own safety, but also for the safety of the children, particularly if post-separation the children would have to have extended unsupervised time with the father. Narelle told us:

The reason why I didn't leave [earlier] was the Shared Parental Responsibilities Act. I knew the changes that were coming. I knew that if I had kicked him out then he would have got 50/50. I did what I did [staying] to protect her [daughter]. You know some people might not agree. But I did what I did to protect her. 
All the women expressed support of the father/child relationship insofar as they wanted these to be maintained but only in contexts that ensured the children's safety. Initially Bronwyn, for example, attempted to balance these incongruent goals as follows:

$$
\begin{aligned}
& \text { I have to... let her have a father and do the right thing. What I thought } \\
& \text { was the right thing at the time [supervising daughter/father visitation]. } \\
& \text { I messaged him asking did you want to see her? He ignored Wendy } \\
& \text { altogether...[contact was supervised] because he's not a very nice or } \\
& \text { safe person. }
\end{aligned}
$$

Negotiating parenting with perpetrators of IPV is fraught with risk. Invariably interviewee attempts to maintain father/child relationships resulted in further harm. Child contact provided fathers with a readymade avenue for abuse. Every woman reported living with post-separation coercive control including: 1) threats and intimidation, 2) humiliation, degradation and emotional unkindness, 3) restricting personal territory and freedom, and 4) crazy making. ${ }^{17}$ Belinda's story is typical:

It was just all awful...he was being very controlling regarding the children and everything was on his terms. Any dealing with him was incredibly difficult and he would be quite abusive towards me... basically calling me crazy, mental health issues, insane, unreasonable, drama, just create drama. Very controlling language, like if you dare do this I will do this, basically making me feel I had no rights, no say, no nothing. It's psychotic... he's threatening to contact Department of

\footnotetext{
${ }^{17}$ This involves making the victim think they are going crazy. Also known as 'gas-lighting', it is a tactic used by some abusive men as part of their psychological attack. (For a discussion of the term 'gaslighting' see Calef and Weinsheln, 1981).
} 
Foreign Affairs and tell them that the kids aren't allowed to travel... he invents dramas all the time, conflict. He lives for it.

Post-separation, the questionable parenting capacity of perpetrator fathers persisted and, in many instances, worsened. Some men continued to exhibit a disinterest in primary childcare. They would return children early or fail to take them during agreed visitation times. The following examples demonstrate these types of behaviours:

Then I offered him time with Wendy because I felt like I should, and when I offered it - he hadn't asked - he made out this big deal like well I was supposed to be going house hunting that day. (Bronwyn)

He brought her back early, [took her] to the day care centre [early]. Last Sunday he had her, I got a phone call. He's not supposed to ring but, oh my car's broken, I'm bringing her back. (Donna)

Children continued to be exposed to the deviant and neglectful behaviour of their fathers during post-separation visitation. Bronwyn described the following incident to us:

He was in [the shed]. That's where he used to smoke marijuana. He was in there with Wendy. It was dark. It was quite well into the evening by this time ... her nappy was so wet it soaked all her clothes. She was frozen. She was shivering.

Children further witnessed their fathers perpetrating abuse against their mothers at hand-overs. Olivia told us: 
Then by that stage the girls didn't want to get out of the car, he's yelling out, you're just telling them I'm a "fucking monster" and all this stuff. Next day rocks up with balaclava mask on to give me back the kids. "You want to fuck a monster?" Tries to flog me at changeover, drags the kids through the carpark at changeover, dragged my baby's body all through the carpark [crying].

Interviewees identified further examples of perpetrators' use of children as including: requiring the children to monitor and report on their mothers' lives, denigrating the mother and attempting to fracture the mother/child relationship, withholding financial support from the children, and threats to remove the children as well as refusing to return the children to their mother's care. For example, Mary described:

He'll ring the kids. He rings the kids every day that they're with me and the first question he always asks them: Is mum there with you? Because he's checking on where I am, what I'm doing. If I'm not there, if I happen to be out with friends, he asks them where I am, what I'm doing, who I'm with.

Removal of children through family law proceedings was noted as providing perpetrators with a way to control, harass and intimate their victims.

Olivia explained how when she refused to reconcile with her violent ex-partner he used family law proceedings as a way to threaten and intimidate her.

He's like: "I'm going to take these kids off you. I'm going to tell them you're a fucking bad mum”, da-da-da-da. So then I go to mediation [at] 
some family law firm...the law guy goes look, you're going to have to give 50 per cent custody to him....

Then when things had not been sorted out Olivia got a letter from the father's lawyer saying:

I need to give him three overnight access straightaway and he'll be going to five days and then week about and if I don't do that it won't be seen very nicely in the Family Court. Then the Family Court stuff starts ... he's threatened this whole time he's going to take the kids off me. That's exactly what the Family Court ... let it happen, despite everything.

According to the interviewees, fathers continued to perpetrate IPV and regularly neglected their children's safety. Court ordered time with a violent father removes the ability of women to protect their children from on-going paternal abuse. These feelings of maternal powerlessness and concordant trauma are illustrated in Narelle's story:

My oldest has PTSD and anxiety [due to living with IPV], but you know what I'm afraid of? Her father won't have to kill her, she'll kill herself because she can't take it anymore. She's already said to me: "I would rather be dead. I want to die." How am I supposed to answer that as a mother? They have to go [court ordered visitation as a result of a FRW's recommendation]. She loves her dad, they both do. They know what he's done is wrong. She said to me, "Mamma, if I have to go and stay at daddy's who's going to protect me?" She cried and cried and 
cried. I can't protect them and that's what this family report writer should have done. It's out of my hands.

The women reported that the IPV they experienced left them socially isolated, humiliated, vulnerable and feeling powerless. In line with societal expectations of mothers (Midson, 2014; Morgan \& Coombes, 2016) our interviewees wanted to keep their children safe - and that is why they told their stories of violence to the FRWs. Yet their experiences of this process variously proved to be challenging, traumatising and sometimes even re-victimising, as we discuss next.

\section{Experiences of Family Report Writing Practice and Process}

The point at which mothers who are victims of IPV enter the family law system is often a point of collision between their accustomed role as protector of the children and a system which berates them, and even sometimes appears to punish them, when they do not obligingly facilitate the children's relationship with an abusive father post-separation. Family reports embody this collision. As noted above, compiling a family report is complex, requiring great skill and knowledge about a wide range of issues which affect families. It is a forensic process, very different from the therapeutic work that most social scientists undertake at the beginning of their professional lives.

Many of the women saw more than one FRW and some preferred one to another. From the data available to us, there were a total of twelve FRWs involved with our interviewees, with two coming up twice. They were all social workers or psychologists. Most were in private practice. Some were court-based family consultants, others held a regulation 7 appointment, but with others their official position/status was unclear. From the resumes attached to the family reports (noting again that we were not able to read the family reports themselves) we 
ascertained that generally the FRWs had significant experience in their profession, ranging from ten years to over 30 years, although not always in family counselling and forensic assessment.

Although all of the women reported concerns about how IPV was dealt with in the family report writing process, some also made positive comments about the FRWs. Ursula said: I think he described what I told him accurately in the report. When I read over that earlier this morning I thought yep, he's got me pretty right.

Donna was happy with the first family report which was prepared at the court:

... it was very fair ... I thought it was fair on both sides, not just my side, but both sides.

However, the women's accounts indicated ways in which FRWs were able to make recommendations to the court that 'on the face of it' appeared incongruent with IPV context to the relationship. At best, assessment environments and methods presented as in need of improvement. At worst, the process was experienced by the participants in our research as revictimising and traumatising. The mothers described a system in which they felt their experience of IPV was discounted, ignored and invalidated. Isabelle summarised her experience as follows:

This is how a court report feels - it's like standing on a beach, [starts to sob] holding your children's hands and having a tsunami just coming towards you - and you try to run yourself but you're also trying to protect your children because the tsunami is like your ex-husband plus all the officials plus everything.... But you're just trying to stand still so that somehow you hope that the truth comes out. (Isabelle) 


\section{Assessment Process - time, place and arrangements}

Typically, family report assessments were reported as being conducted over a few hours in offices located either at the court or off-site. However, one woman told us that her assessment took place in a hotel room:

Then we had the family report. It was a social worker, he was called [name]. He was quite old. We had to go to a hotel in the city to do this report. It was in a room. Like a hotel room. It was weird and I felt very uncomfortable. (Bronwyn)

The women reported that their assessments included interviews with them, perpetrator fathers and their children. FRWs also observed children interacting with both parents. The women felt that the assessment process was questionable given its brevity. Olivia stated, "there was a two-hour interview... two hours is not long enough, do you know what I mean, when things [IPV] have happened."

The women communicated apprehension with regard to how, given the time constraints and clinical environment, FRWs were able to accurately gauge the parenting capacity of victim mothers or perpetrator fathers. The mothers expressed concern that their children's responses to them and perpetrator fathers were de-contextualised as a result of the unfamiliar and artificial assessment environment.

For some mothers the FRW assessment process resulted in further abuse and trauma to both them and their children. For example, even when FRWs were aware of the IPV, some mothers found themselves being required to be in the same physical space as the perpetrator. Olivia explained the distress created when this happened: 
[The FRW] is fully aware that there's DV but makes the two of us rock up at the same time to have an interview. What does she think was going to happen? If she had read the material prior to the interview then she wouldn't have made the interview like that, that's what I would have assumed. No, no. The lady - one, she rocks up half an hour late. That gave him half an hour to start.... He starts having a crack at my mum.... The kids are screaming their heads off. She arrives to two kids screaming their heads off, a situation happening in front of her.... She's like: "sorry, I had to get a coffee, I'm just having one of those mornings".

Interviewees told us that the process of forcing of victims and perpetrators together was experienced by them as a deliberate approach on the part of the FRWs in attempting to assess the truthfulness of IPV claims by gauging reactions. For example, Narelle stated:

She didn't stagger our times. Even though I had a domestic violence order. She made us wait in the same waiting room. If you actually read the family report you can tell that she had done it on purpose. Of course, I've seen my ex and I've immediately, oh my God. He's in the same waiting room as me. That really put me off balance. I can now see that she was trying to gauge my reaction. I think that's despicable to be quite honest. I think it's despicable when she knew that I had a domestic violence order and the children were named persons on that order.

\section{Interpreting parents}


As discussed earlier, it is a known characteristic of perpetrators of IPV that they are highly manipulative and can come across as very calm, rational and charming. A strong appreciation of this is important in family report assessment processes to achieve an accurate assessment of the perpetrator's parenting capacity, particularly in the context of the time poor and artificial environment in which the assessment process usually occurs. Children who live with IPV usually still love the abusive parent and the FRW's office is a controlled interaction space where perpetrator fathers, under the supervision of the FRW, are inevitably on their best behaviour. As a result, the perpetrator and child interaction within the family report assessment locale can be questioned in terms of whether it accurately reflects reality. It follows that it is extremely challenging to draw appropriate conclusions about parental capacity in such an environment. Olivia told us:

The kids' reaction to him [the father] ... they're looking at her [FRW] looking at him, looking at what the hell's going on. Their behaviour is not the same either because they're thinking: "Oh, Dad's usually yelling and screaming at mum. We're usually quiet. We're usually scared but he's actually quiet today. What's going on here?" So they're as shocked as everyone else, but such a clinical environment what do they expect is going to happen? Oh, you think he's going to do what he does at changeover? Do you know what I mean?

In terms of maternal parenting capacity, the women explained that FRW assessments were experienced as disruptive to routines and by extension, exhausting and stressful for children. The mothers questioned how FRWs were able to accurately gauge their parental capacity under these conditions. Once again, it was felt that children's behaviour needed to be contextualised within the domain of the assessment process. Jane, for example, told us that the 
FRW in her case interpreted her son's refusal to play with her as indicative of maternal incapability rather than as the response of an exhausted infant:

I brought Ethan to play with the father then when Ethan played with the father, the father left and I came to play with Ethan... Ethan was tired ... it was his sleep time and the FRW wrote that my son didn't want to play with me, that I had no insight on parenting that ... basically I've got no idea, so that's how she's [FRW] described me. That my son didn't want to play with me which is totally incorrect, because if she only had a child, well a child driven from Brisbane to Ipswich one hour. Then he had played with the father for 40 to 45 minutes, of course he's fine, you know, because that's his first play. Then she [FRW] wants the child to play in the most small little room than this probably with not even a couple of chairs, very very ... I don't know how to explain.

The behaviour of Narelle's young daughter toward her is also subject to a process of decontextualisation. The FRW took the view that Narelle's children were unhappy with her in the waiting room. Narelle's perspective was that her young daughter was not happy because she was unwell, exhausted and had been forced into a foreign environment for half a day. Narelle told the FRW that her daughter was sick but this was not taken into account. She relayed:

[The FRW] was saying that oh, the kids were unhappy and everything in the waiting room with me. It's just like she [FRW] obviously didn't listen to a word I said. I had to go and find a chemist that morning because my child had a temperature of 38.3. This was the youngest. My four year old. I wasn't familiar with that area because I'd never been to 
that area of Brisbane before. I was dragging the kids around trying to find a chemist to buy her Panadol to get her fever down. I'd been up with her for three days. I had virtually no sleep for three days because she had really high fevers. Then she [FRW] puts in the report, after I'd told her that she'd been sick and having fevers and everything, that they appeared really unhappy and silent and all this other stuff. I'm thinking, did you not listen to a word I had to say?

Some interview techniques were experienced by the women as harsh and interrogating. Isabelle described her interview experience and the traumatic repercussions for her as follows: [The FRW] seemed to just fly at me verbally ... this is my room, this is how I'm going to conduct myself and this is a process and you will answer the questions. Very threatening. I actually felt quite fearful - not fearful of him - just when someone's right in your face. You know when someone can get physically in your face and your heart starts beating and you go into that fright mode. [After the interview]. My legs were shaking ... I cried and collapsed - you go into kind of numb... you share so much of your love and your life and you're in defensive mode - but you're trying to come across as normal .... Court reports are very much entrenched in fear for mothers .... But the stress of the day, it was almost inhumane to have to - the process takes away your - it's like your selfesteem and your self-confidence and everything that you know who you are, is really violently challenged in the way that they talk to you and the way that they express themselves. They have no experience of domestic violence. 
As is the case for adult victims of IPV, creating an interview environment in which traumatised children can feel safe enough to open up can take time and high degree of therapeutic expertise. Narelle told us, "because when you have a child that doesn't know this person [FRW], asking all these questions, they've got no relationship with that person".

Some mothers explained that their children experienced the interview process as retraumatising. Narelle and her children, for example, were subjected to more than one assessment. Narelle told us that after the first FRW process her daughter would go "on hunger strikes ... she came out and she cried after we'd gone. She cried and she went on a hunger strike. She lost kilos". When called back for subsequent assessments Narelle's daughter would stop eating again. She stated, "I don't know why we have to keep going through over and over and over again the same stuff we've already told them. I don't like it. I'm a grown up. [My daughter] she suffers".

\section{Talking about IPV}

Mothers reported that they found talking about their IPV victimisation with FRWs difficult. This is unsurprising given that these appraisals were taking place with traumatised victims, over condensed timeframes in unfamiliar and formal surroundings (such as an FRW's office). Fiona, for example, explained that "it's not long enough and it doesn't give enough time...it's very hard to talk about it [the IPV]" and went on to explain that, at the time, she was too "tangled" in her brain. Ursula felt uncomfortable talking about the violence in a room so close to her children saying, "when your child is over there in the next room and there's a door between you and you're talking to someone about the abuse that someone did to you that was their father, you don't really probably want to talk about it". 
The women's narrations of their FRW experiences indicated that they felt their perspectives were not adequately validated in the process. They recounted how the abuse they and their children had lived with would be minimised, dismissed or completely negated by FRWs. Bronwyn argued, "where there is domestic violence and especially where there is actual evidence, they [FRWs] should damn well listen to it. They shouldn't minimise it or ignore it or make out that it's not relevant or that it doesn't matter". Ursula similarly said, "[The FRW] didn't deal with the violence at all. I'm sorry but I want my children to be raised in a non-violent place". She went on to express exasperation about what the FRW had expected from her as a mother:

What does he [the FRW] want me to do? I could stay with him [perpetrator father] to protect my children and I will be beaten up for the rest of my life - I don't think I have the mental capacity to deal with it anymore [but] I would rather that than for him to have unsupervised time. The thing that he's [FRW] not understanding is [IPV] he's not addressing that.

The women explained that their experience of the invalidation of IPV played out in a number of ways. First, it was a common experience that FRWs seemed determined to silence their victimisation experiences. Some FRWs failed to ask about IPV and, if the women raised it as a concern, this was quickly dismissed. Jane told us, "she [FRW] shut me off ... she so strongly made a point about it that [she didn't] want to know". Second, when IPV was acknowledged, consideration of the parenting capacity of abusive men was nullified by presenting it as extraneous to parenting. Bronwyn explained: "they [FRWs] don't want to know about domestic violence. They want to pretend it doesn't happen. Even when they can't deny that it happens, they have this whole attitude that it doesn't make him a bad father. I disagree”. 
In addition, the participants in this research reported that the possible future risk posed by perpetrators to the safety and welfare of victim mothers and their children were commonly dismissed by re-constituting the abuse as an act from the past with no bearing on the future, something that the victims needed to "get over". Jane said, "the FRW straight away said to me ... I don't want to hear anything about your past domestic violence”. Mary was berated for trying to discuss past IPV as a concern and scolded by the FRW for expressing fear of the perpetrator father:

She [FRW] wanted to focus on well what's happening right now and so I was really confused by that ... she's like "Is he threatening you right now”? I'm like "no". She's like "Well is he being physical with you right now?" and I'm like "no" - and she's like "I don't want to hear about what's happened prior, I want to know what's going on right now" ... I'm like "Well he can't come near me [due to an interim court order] so, no, he's not out the front of my house checking what I'm doing; no, he's not choking me because he can't be near me enough to hurt me. He's not doing anything to the kids because he's having supervised visits for two hours every second Saturday ... she's like "Well how do you feel about him now?" and I'm like "I'm scared” and she's like "But what have you got to be scared of?"

Jane also explained to the FRW that her husband had sexually assaulted her on numerous occasions. However, it was her perception that the assaults were presented by the FRW as consensual and, rather than acknowledging Jane's experience, she was presented as the problem. Not only was Jane's experience of IPV ignored, but the assaults were described as Jane's "sexual exploits" with her ex-husband and she was presented as someone who engaged 
in sexually deviant behaviour rather than as a victim of IPV seeking to ensure her safety and the safety of her child. Jane told us:

He [the FRW] wasn't interested in the past domestic violence but he was interested in my previous sex partners.... Also, my ex-husband would only want anal sex and the way I said it to [the FRW] that he constantly wanted [anal sex] and I refused and that's why he was angry... The way he [FRW] puts it on a piece of paper [family report], he says, 90 per cent of their sex life was anal. I thought this is just so not correct ... it was very offensive.

The women's stories clearly point to the FRW process as being experienced as a traumatising journey. An overarching concern expressed by the women was the invalidation of their experience of IPV and its consequences. The literature strongly establishes that victims of IPV are impacted negatively by the violence perpetrated against them, and this impact is commonly significant and long-lasting. The minimisation of the lived experience of IPV resulted in the women in our study feeling re-victimised by the very system from which they sought support and protection for themselves and their children.

\section{Sense of mistrust and feelings of blame}

The participants in this study reported that apprehension about discussing their experience of IPV and its consequences was further exacerbated by what was construed by them as FRW ambivalence about, insensitivity to and/or mistrust in the truth of the victim mother's account. During her interview Narelle worried about the impact of recounting her experiences because the FRW questioned the truthfulness of her account and Narelle came away feeling like a "criminal": 
I did not want to go through every single instance with her when I knew that I was going out to my kids soon ... I knew that I would get really upset and I just said look it's all in my affidavit ... [the FRW said] "Anyone can put anything they like in an affidavit. It doesn't mean it's true" ... I feel that I was treated like a criminal from the very beginning because ... I was trying to ... protect the children because nobody else will speak for them.

Donna described her experience of a level of ambivalence and insensitivity to her story exhibited during the interview as follows:

She [FRW] just wanted nothing to do with me [when trying to speak about victimisation experiences]. She kept looking at the clock above my head...She was very rude, no compassion. Like even when I was trying to tell her stuff that happened sexually and she goes "So what are you saying, he put his hand around the thing and raped you?"

Finally, the women in our study reported that the FRWs they encountered had a tendency to invoke normative misconceptions around gender as a further avenue to invalidate abuse. Here, women were seen as lacking credibility. Despite being told not to recount her experiences of IPV, Jane went ahead and described a particularly ruthless attack to the FRW. This was promptly dismissed as a fabrication of the truth. Jane told us, "[the FRW writer] says I paint a very unrealistic picture". Jane retold the story of this attack and subsequent response by the FRW as follows:

[This day] he [the father] was choking me badly in the carpark building because he hit Ethan and when he hit him a second time I stood up, I 
said you could break his spine because he's too little and he was crying.

Keith wouldn't allow me to cuddle him. He grabbed me and he said,

“You shut up shut up. You're a liar. I didn't hit him. No one will ever believe you"... holding me by the throat. [The FRW] twisted [this event] ... to be as if I lie.

The women in our study felt that FRWs who distrusted the truth of their story, also saw any reluctance on their part to facilitate unsupervised time with the father as unreasonable and obstructive behaviour. When children were averse to seeing their father or made direct disclosures about his abusive behaviours this was also discounted or reframed by FRWs as evidence of problematic mothering rather than identifying the behaviour as the perpetration of paternal IPV. Consistent with the literature, many of our interviewees were accused of alienation in some way during the report writing process. Bronwyn stated, "she [the FRW] thinks I am some brainwashing, alienating guru or something, I wish I could brainwash my daughter to pick her socks off of the floor". In another example, Narelle's daughter made direct disclosures of abuse to the FRW, but this was dismissed and reframed as being a maternal rather paternal parenting problem. Narelle was also described as an alienating mother. She explained:

Of course they love their father. He's their father. So for her [Narelle's daughter] to have the courage to come out and say exactly what her father was doing to her and then know that FRW thought she was a liar. Do you know how damaging that is for a six year old? Then from that I've got accused of being actively alienating the children and coaching and rehearsing the children. But [all I did was] read them the family consultant brochures, which it states you're allowed to do. I said to 
them both, you're going to meet a lady, she's going to ask you questions about mummy and daddy, just tell her the truth.

The mothers in our study explained that they supported the father/child relationship but wanted their children to be safe, and their attempts at protecting their children were often interpreted as irrationality, anxiousness, hysteria, unfriendliness, alienation or an indication of an unhealthy maternal enmeshment. As Donna explained to us, "I want her to have a relationship [with her father] but I want it to be in a safe environment". Narelle's view of her ex-partner was seen as "coloured" and she was accused of "alienating" her children from their father. Mary's anxiety toward unsupervised contact was repositioned as an "unreasonable" fear of her abusive ex-partner. To better support the perpetrator/child relationship Mary was supposed to address this "irrational" fear and the FRW recommended that she attend therapy. She protested, “don't tell me that I need counselling about that because it's completely irrational behaviour [fear of the father]".

Bronwyn was also criticised for being unsupportive of the father/child relationship; accused of maternal "enmeshment", utilising "brainwashing" techniques, "alienating" and causing her daughter to develop a "phobia of her father", using breastfeeding as a ploy to withhold overnight access and berated for previously stopping father/child contact. Some of these points are outlined by Bronwyn below:

They [FRWs] didn't really listen. They didn't seem interested [in the domestic violence] ... they'd go back to whether or not I would support his relationship [with the daughter], why I had stopped the contact. That was a big one, was why I had stopped the contact... Probably of anything, that was the bulk of the discussion. Because at one point, I stopped contact because he'd [father] gone off [verbally abusive] at my 
friend and I and he was clearly quite out of it [high on drugs]. He [FRW] was talking to me about not facilitating the relationship and not supporting the relationship. That it was serious to withhold a child and it would damage Wendy's relationship [with her father] and her development. [The FRW] said that he didn't see any reason why she couldn't have overnights [with her father] and that I was breastfeeding as a tactic [to withhold overnight access].

\section{Outcomes for Study Interviewees}

A range of final outcomes resulted for the interviewees in our study. Donna advised us that the FRW in her case recommended ESPR and that the matter was finalised by consent with the child living with her and the father having regular overnight weekend contact and other time. Jane told us that the FRW recommended that the child be removed from her and placed with the father and, at the time of her interview, she was very fearful of the approaching trial. Legal aid had been withdrawn after the first report. Belinda advised that that final outcome in her matter was ESPR to the father (although she was given sole responsibility for one health issue) and regular unsupervised time with the father.

Fiona's case was subsequently finalised with an order for ESPR and regular weekend and school holiday contact for the father. Fiona and her former partner live over 400 kilometres (275 miles) apart so the father travels to Fiona's town where he stays in a caravan park for the weekend visits. School holiday changeovers involve both parents driving to a half-way point where there is a Contact Centre. Fiona has experienced significant difficulties dealing with dental work 
required by the children because the ESPR status means that the father's consent must be obtained for all procedures and he has not been obliging in this regard, thereby delaying urgently required treatment.

In Ursula's case the FRW recommended that the children spend time with the father every second weekend. According to Ursula, by the time of the trial which was nearly a year later, difficulties at the Contact Centre meant that contact with the father had effectively been suspended. However, the FRW did not change his opinion at trial and the judge ordered a graduated return to contact. There was evidence from an expert witness that the father had a narcissistic personality disorder or at least narcissistic traits. The contact arrangements again proved unsuccessful, the father brought breach proceedings and the parties were involved in litigation concerning their financial matters into 2017. The case finally settled when the father agreed to have no contact with the children on the basis that certain financial orders against him be dismissed and that he not be liable for child support.

For Bronwyn, in early proceedings an order was made for the infant to live with Bronwyn and spend every second day from 9 am to $6: 30 \mathrm{pm}$ with the father, although Bronwyn was still breastfeeding. This case was finalised by trial subsequent to the interviews. Bronwyn advised that the father proposed the child live with him. Bronwyn's allegations of violence were never really believed but she was awarded sole parental responsibility due to other complex factors in the case. Contact with the father, which had not been occurring for some time, was to be reestablished in the context of intensive counselling. 
Isabelle was the one exception in our sample where the FRW suggested that the father may have engaged in alienating behaviour. In her case, a number of family reports were prepared and she informed us that the final family report made a number of alternative recommendations depending on whether or not the court found that the father had alienated one child. However, Isabelle's lawyers were concerned by negative comments about her made by the possibly alienated child and, on advice, she settled on a 50/50 arrangement. In practice the alienated child now lives only with the father and has very little contact with the mother, while other children live in a shared time arrangement.

\section{Suggestions for Reform}

Our interviewees were asked to suggest ways in which the FRW process could be improved. In line with previously expressed concerns, their recommendations included: a) increasing levels of IPV awareness and expertise among FRWs, b) creating a safer, less sterile and intimidating assessment process, c) making the assessment process more thorough, d) increasing FRW accountability, and e) increasing FRW willingness to listen to victims and take their experiences of IPV seriously.

\section{Increasing IPV expertise}

The negative experiences of our interviewees in the family report assessment process resulted in a sense that the levels of awareness and expertise in FRWs about IPV need to be increased. A requirement for further and ongoing training in IPV was suggested as a positive response to this need. Narelle contended:

The first thing is that they [FRWs] must have expertise in domestic and family violence. That is a given ... they must prove that they have the 
relevant expertise to deal with the issues that are being raised ... they need training. I'm not talking about a one-hour session. I'm talking about regular ongoing training. They should have to pass an exam. You go college. You study a subject. They're going to give you an exam aren't they? It's not the way the situation is at the moment the way they appoint them. It can't be that. They have to prove that they know about domestic and family violence.

\section{Creating a safer, less sterile and intimidating assessment process}

The women expressed that the FRW assessment process could be improved through the provision of a less sterile, safer and less intimidating environment. For some this would mean moving the assessment process away from offices situated at the court. Bronwyn stated, "I think that a family report probably should not be in the court building, honestly. I'm not sure I will ever even get Wendy into that building again if they tell me to".

More broadly the women articulated an urgent need for FRWs to reassess the efficacy of their interactions with IPV victims. Perhaps a more trauma informed assessment approach would be useful. Thus, rather than interrogating victims, FRWs might consider a more empathetic approach. Narelle argued this point as follows:

Court reporters [should not] make women feel [they] are the defendants ... they actually need to treat them like human beings. We've birthed these children - we've brought them into the world ... sacrificed.... We need to be treated with respect ... court reporters see you like a-okay, we're here to do business. It's like a business meeting, but it isn't a business meeting to us. It's our lives. It's our passion. It's 
our children. It's very emotional for us. I think the Family Court reports

shouldn't be abusive in themselves. I think they should be respectful.

In the alternative, it was suggested that some of the adverse impacts of the assessment process might be reduced if IPV victims were fore-warned that the process would be emotionally difficult, supported to prepare for the challenges they would experience and if they were to receive support post-assessment. Isabelle explained:

You don't understand that you're going to be ripped to shreds ... and that you might need some emotional support afterwards.... That would be really beneficial ... families they actually need support when they're going through the court report ... they need a counselling session or two afterwards, to unravel the process.

As protective mothers, the women further recommended ways in which children might be better supported and in turn safeguarded during the assessment process. The mothers likened the interrogatory nature of the family report assessment process to the questioning of children by police and the giving of court evidence in criminal matters. However, in these situations, children are provided with an independent support person with expertise in child trauma. Interviewees therefore suggested that an independent support person of this kind should be provided to children when they are being interviewed by FRWs:

I think it would be good for some child orientated person to be there ... that they can maybe meet the week before or the month before, build a little relationship...they know them - it's comfortable - children often won't want to stay in the room anyway, with a brand new stranger - and then for them to be able to debrief the children afterwards in another 
appointment. See Family Court reports have to be child-centred. (Isabelle)

\section{Making the assessment process more thorough}

Overwhelming concern about the time poor nature of the assessment environment led the mothers to suggest that additional time was needed with families. Mary told us "yeah, [more time] and maybe more than just the one session, even if they make it shorter sessions more frequently". Isabelle stated, "more time is needed to undertake the evaluation". Ursula suggested undertaking interviews with parents and children on two separate days. This could reduce anxiety in mothers who may feel uncomfortable talking about their trauma with children close by.

It was also suggested that the process could be made more comprehensive if FRWs utilised more information sources beyond the assessment interviews and parent/child observations. As noted by Isabelle "there was plenty of evidence [of domestic violence]. She [FRW] ignored the stuff'. Isabelle suggested that perhaps FRWs might want to consult with the children's regular therapists and Bronwyn said, "they need to talk to [the] teachers".

\section{Increased accountability}

FRWs are provided with special protections. These special protections were questioned on the grounds that greater accountability for assessments could increase victim efficacy. Narelle argued:

There's one thing that I can think of off the top of my head that needs to change and immunity needs to be gone. Because if they didn't have immunity and they knew that they could get their arses sued off, I believe that that will start to change the system... It's just like if he [perpetrator 
father] does kill them [the children], they're [FRWs] not held accountable. They're not held accountable.

\section{Willingness to listen and take IPV seriously}

Finally, and perhaps most importantly, given overwhelming concern about the silencing of victim voices through unfriendly and intimidating assessment environments and mechanisms of invalidation, interviewees offered the view that IPV should not be negated or ignored by FRWs. Rather FRWs need to be open to hearing the narratives of victims and take any disclosures of IPV seriously. Bronwyn stated, "[FRWs] just need to listen and understand this stuff [IPV]". Ursula commented, "domestic violence should be taken very seriously". Isabelle said, "there needs to be a process of acknowledging the domestic violence within the Family Court report”. Narelle was nevertheless sceptical about whether this can be achieved within the broader pro-contact stance of the court. For Narelle, FRWs adhere to a family law system which appears to silence victims of IPV and follow the family law message of maintaining a relationship with the father. She stated: "I truly believe that they are doing what they expect the judges want them to do."

\section{PART V: Conclusion}

Through in-depth interviews the research presented in this article explored the practices of FRWs from the perspective of mothers who lived with IPV. These women reported extensive histories of IPV perpetrated against them by the fathers of their children. This violence eventually led to the dissolution of their intimate relationships but as is common with coercively controlling men, the abuse continued post-separation. Perpetrator fathers frequently used their children as tools of abuse against victim mothers and, more generally, parented in negative ways. In line with the previous extant research, mothers described a FRW system they 
perceived as being resolute on invalidating IPV, an assessment process lacking in victim efficacy and outcomes that often put women and their children at on-going risk of harm (see (Hemphill, 2013; Jeffries et al., 2016; Kaspiew et al., 2015a; Kaspiew et al., 2015b; Moloney et al., 2007; Shea Hart, 2011). The women expressed an urgent need for FRW practice to change.

The narratives of these mothers show that the family report assessment process is complex and challenging, but also that a number of relatively readily achievable improvements are identifiable. For example, stronger IPV training and continuing professional development requirements could be introduced to ensure that FRWs have the necessary level of IPV awareness and expertise; the environments in which assessments are conducted could be made safer, less sterile and less intimidating; the assessment process could be made more thorough with the inclusion of interviews of professionals (such as doctors, psychologists, teachers and police) who have a knowledge of the family and its context; FRW accountability could be increased; and a culture could be developed within the FRW community reflecting a willingness to listen to victims and take their experiences of IPV seriously.

Although a significant body of guidelines and practice directions already exist in Australia (Hemphill \& Hugill, 2015), not all FRWs are bound by them. Narelle was one interviewee who raised concerns about the lack of FRW accountability. Both accreditation and accountability of FRWs is problematic. As noted above, some professionals in this study who prepared documents called 'family reports' did not appear to hold any formal appointment. It is suggested that a clearer more rigorous accreditation process be developed with clear criteria about the qualifications and experience needed to be accredited as a FRW, including expertise in IPV, and also requiring on-going professional education. 
Despite the fact that the courts "receive a reasonably significant and ongoing volume of complaints about family consultants' performance in individual cases" (Wareham, 2015) there are a number of blockages in creating any genuine complaints' avenue, including:

- FRWs are accorded the general immunity of expert witnesses as well as a special legislative immunity which is the same as judges; ${ }^{18}$

- the relevant professional bodies, the Australian Association of Social Workers and the Australian Health Practitioner Regulation Agency (AHPRA,) cannot investigate complaints because they would be breaching the publication section (FLA s 121) which prohibits publication of family law documents which would identify parties - clearly essential in a complaint;

- during the currency of any proceedings it is considered that the avenue for challenge exists by way of cross examination of the FRW and judicial oversight. Obviously, this is extremely challenging for a self-represented litigant - even an experienced and clever advocate may have difficulty exposing unconscious bias or deeply held beliefs in an expert witness;

- complaining after proceedings have been finalised is not helpful or emotionally viable for litigants who believe that inappropriate orders have been made partly on the basis of the family report.

Consideration could be given to establishing an independent unit where complaints about FRWs can be lodged. It would ideally cover both private report writers and employees of the court. ${ }^{19}$ Consultation with relevant stakeholders would be required to develop an appropriate model, but it must have the ability to read family reports, investigate, dismiss obviously frivolous vexatious complaints and take action where complaints are substantiated.

\footnotetext{
${ }^{18}$ FLA s $11 \mathrm{D}$

19 This is under consideration in the current review of the family system. See: Australian Law Reform Commission, 2018.
} 
This centralised system would ensure early warning of FRWs who received high numbers of similar complaints.

Developments in family report assessment practice require leadership from Government in the form of legislative and regulatory reform, but also in the form of a serious investment of resources and funding. This research indicates that the current system is not producing safe or appropriate outcomes. To ensure that children and their mothers are protected from harm, and to ensure that they can have futures living free from violence significant action to improve the family report assessment and writing processes is required. 


\section{References}

Abbassi, A. and Aslinia, S. D. (2010) Family Violence, Trauma and Social Learning Theory, Journal of Professional Counselling: Practice, Theory and Research (38) 16-27

Association of Family and Conciliation Courts (2016) Guidelines for Examining IPV: A Supplement to the AFCC Model Standards of Practice for Child Custody Evaluation, 2016 at

http://www.afccnet.org/Portals/0/Center $\% 20$ for $\% 20$ Excellance/Guidelines $\% 20$ for $\% 2$ 0Examining\%20Intimate\%20Partner\%20Violence.pdf

Association of Family and Conciliation Courts Australian Chapter, (2018). $5^{\text {th }}$ Annual AFCC Australian Conference: Alienation? Myths, Complexities and Possibilities ..., Adelaide.

Australian Law Reform Commission (2018). Review of the Family Law System: Discussion Paper 86, Commonwealth of Australia.

Bagshaw, D., Brown, T., Wendt, S., Campbell, A., McInnes, E., Tinning, B., Batagol, B., Sifris, A., Tyson, D., Baker, J \& Arias, P. (2010). The effect of family violence on postseparation parenting arrangements: The experiences and views of children and adults from families who separated post-1995 and post-2006. Canberra: Australian Government.

Bagshaw, D., Chung, D., Couch, M., Lilburn, S., \& Wadham, B. (2000). Reshaping responses to IPV. Adelaide: University of South Australia.

Bancroft, L., Silverman, J \& Ritchie, D. (2012). The batterer as a parent: Addressing the impact of IPV on family dynamics. Thousands Oaks: Sage.

Barnett, A., (2018) Narratives of Hostility: The (Re)Emergence of Parental Alienation in the UK, International Society of Family Law, North American Regional Conference, University of Minnesota Law School. 
Brinig, M. (2005) Does Parental Autonomy Require Equal Custody at Divorce? Louisiana Law Review (65) 1345-1377.

Bruch, C., (2001) Parental alienation syndrome and parental alienation: Getting it wrong in child custody cases Family Law Quarterly 35(3) 527

Bryman, A. (2012). Social Research Methods (4 ${ }^{\text {th }}$ ed.). Oxford: Oxford University Press.

Buchanan, F., Power, C., \& Verity, F. (2014). The effects of IPV on the formation of relationships between women and their babies:"I was too busy protecting my baby to attach". Journal of family violence, 29(7), 713-724.

Calef, V. and Weinshel, E (1981) Some Clinical Consequences of Introjection: Gaslighting, The Psychoanalytic Quarterly, 50:1, 44-66,

Callaghan, J.E.M., Alexander, J.H., Sixsmith, J \& Fellin, L.C. (2018). Beyond 'witnessing': children's experiences of coercive control in IPV and abuse. Journal of Interpersonal Violence, 30(10), 1551-1581.

Cashmore, J \& Parkinson, P. (2009). Children's participation in family law disputes: The views of children, parents, lawyers and counsellors. Family Matters, 82. Canberra: Australian Institute of Family Studies.

Chisholm, R. (2009). Family courts violence review. Canberra: Australian Government.

Cox, P., (2015) Sexual assault and IPV in the context of co-occurrence and re-victimisation: State of knowledge paper: State of Knowledge Paper, ANROWS, Sydney.

Coy, M., Scott, E \& Tweedale, R. (2012). Picking up the pieces: IPV and child contact. London: Rights of Women and CWASU.

Davis, M.S., O’Sullivan, C.S., Susser, K. \& Fields, M.D. (2010). Custody evaluations when there are allegations of IPV: Practices, beliefs, and recommendations of professional evaluators. Washington: National Institute of Justice. 
Denzin, N. K. \& Lincoln, Y. S. (1995). Transforming qualitative research methods. Is it a revolution?. Journal of Contemporary Ethnography, 23(3), 349-358.

Douglas, H. (2012) Battered Women's Experiences of the Criminal Justice System: Decentring the Law, Feminist Legal Studies 20, 121-134.

Dragiewicz, M. (2014). IPV and family law: Criminological concerns. International Journal for Crime, Justice and Social Democracy, 3, 121-134.

Easteal, P \& Grey, D. (2013). Risk of harm to children exposure to family violence: Looking at how it is understood and considered by the judiciary. Australian Journal of Family Law, 27, 59-77.

Ehrensaft, M., Cohen, P., Brown, J., Smailes, E., Chen, H. and Johnson, J (2003) Intergenerational Transmission of Partner Violence: A 20-year Prospective Study Journal of Consulting and Clinical Psychology (71), 741

Family Violence Committee of the Family Court of Australia (2013) Family Violence Best Practice Principles, Family Court of Australia.

Fidler, B., Bala, N., and Saini, A. (2012) Definitions and Debates in Children Who Resist Postseparation Parental Contact: Differential Approach for Legal and Mental Health Professionals, Oxford Press Scholarship Online.

Field, R., Jeffries, S., Rathus, Z \& Lynch, A. (2016). Family reports and family violence in Australian family law proceedings: What do we know? Journal of Judicial Administration, 25(4), 212-236.

Fields, M.D. (2008). Getting beyond 'what did she say to provoke him? Violence Against Women, 14(1), 93-99.

Gillindger, B \& Goddard, C. (2007). IPV: What are the impacts on children? Australian Psychologist, 42, 66-77. 
Graycar, R. (1989) The Child Custody Debate in Australia.in C. Smart and S. Sevenhuijsen (eds) (1989), Child Custody and the Politics of Gender, Routledge, pp 158-189.

Hans, J.D., Hardesty, J.L., Haselschwerdt, M.L \& Frey, L.M. (2014). The effects of IPV allegations on custody evaluators' recommendations. Journal of Family Psychology, $28,957-66$.

Haselschwerdt, M.L., Hardesty, J.L \& Hans, J.D. (2011). Custody evaluators' beliefs about IPV allegations during divorce: Feminist and family violence perspectives. Journal of Interpersonal Violence, 26, 1694-1719.

Hardesty, J.L., Haselschwerdt, M.L \& Johnson, M.P. (2011). IPV and child custody. Illinois: University of Illinois at Urbana-Champaign.

Hay, A. (2003). Child Protection and the Family Court of Western Australia: The experiences of children and protective parents. (Paper presented at Child Sexual Abuse: Justice Response or Alternative Resolution, Australian Institute of Criminology, Adelaide.

Hayes, S \& Jeffries, S. (2015). Romantic terrorism: An auto-ethnography of IPV, victimisation and survival. London: Palgrave MacMillan.

Hendry, L., (17 May, 2018) Parental Alienation Used as "Secret Weapon” in Custody Battles, Says Expert, CBC News, Montreal, https://www.cbc.ca/news/canada/montreal/parental-alienation-used-as-secret-weaponin-custody-battles-says-expert-1.4663869

Hennessy, D. (2012). How he gets into her head: The mind of the intimate abuser. Cork: Cork University Press.

Hemphill, P and Hugall, D., (2015) Australian Assessment Standards of Practice for Family Assessments and Reporting, Family Court of Australia. 
Hemphill, P. (2013). On the crest of a wave: The Australian family violence reforms one year later. Paper presented at the Association of Family and Conciliation Courts 50th Annual Conference, California, 1 June.

Herbert, R. and Mackenzie, D., (2018) Seen and Not Heard: Children in the New Zealand Family Court-Part Two: Lawyers the Child? The Backbone Collective.

Hill, J., (November, 2015) Suffer the Children: Trouble in the Family Court, The Monthly, https://www.themonthly.com.au/issue/2015/november/1446296400/jess-hill/sufferchildren

Holt, S. (2011). IPV and child Contact: Positioning children in the decision-making process. Child Care in Practice, 17, 327-346.

Holt, S. (2015). Focusing on fathering in the context of domestic abuse: Children's and fathers' perspectives. In N. Stanley and C. Humphreys (Eds.). IPV and Protecting Children: New Thinking and New Approaches. London: Jessica Kingsley Publishers.

Holt, S., Buckley, H \& Whelan, S. (2008). The impact of exposure to IPV on children and young people: A review of the literature. Child Abuse and Neglect, 32, 797-810.

Hoult, J., (2006) The Evidentiary Admissibility of Parental Alienation Syndrome: Science, Law and Policy Children's Legal Rights Journal (26) 1-59

House of Representatives Standing Committee on Social Policy and Legal Affairs (2017) $A$ Better family law system to support and protect those affected by family violence, Parliament of Australia.

Jaffe, P. G., Johnston, J. R., Crooks, C., and Bala, N., (2008) Custody Disputes Involving Allegations of IPV: toward a Differentiated Approach to Parenting Plans Family Court Review 46(3) 500-522.

Jaffe, P. G. and Crooks, C., (2004) Partner Violence and Child Custody Cases: a Cross National Comparison of Legal Reforms and Issues Violence against Women 10(8) 917-934. 
Jaffe, P.G., Lemon, N \& Poisson, S. (2003) Child custody and IPV: A call for safety and accountability. Thousand Oaks: Sage, 2003.

Jaffe, P.G., Wolfe, D.A \& Wilson, S.K. (1990). Children of battered women. Thousand Oaks: Sage.

Jeffries, S. (2016). In the best interests of the abuser: Coercive control, child custody proceedings and the 'expert' assessments that guide judicial determinations. Laws, 5(1), Special Issue: Justice Connections DOI: 10.3390/laws5010014

Jeffries, S., Field, R., Menih H \& Rathus, Z. (2016). Good evidence, safe outcomes in parenting matters involving IPV? Understanding family report writing practice from the perspective of professionals working in the family law system. UNSW Law Journal, 39(4), 1355-1388.

Kaspiew, R., Carson, R., Dunstan, J., Qu, L., Horsfall, B., Dr Maio, J., Moore, S., Moloney, L., Coulson, M \& Tayton, S. (2015a). Evaluation of the 2012 family violence amendments: synthesis report (Evaluation of the 2012 Family Violence Amendments). Melbourne: Australian Institute of Family Studies.

Kaspiew, R., Carson, R., Qu, L., Horsfall, B., Tayton, S., Moore, S., Coulson, M \& Dunstan, J., (2015b). Court Outcomes Project (Evaluation of the 2012 Family Violence Amendments). Melbourne: Australian Institute of Family Studies

Kaspiew, R., Gray, M., Weston, R., Moloney, L., Hand, K \& Qu, L. (2009). Evaluation of the 2006 family law reforms. Canberra: Australian Institute of Family Studies.

Kaspiew, R., Horsfall, B., Qu, L., Nicholson, J. M., Humphreys, C., Diemer, K., Dunstan, J. (2017). Domestic and family violence and parenting: Mixed method insights into impact and support needs. Final report (ANROWS Horizons 04/2017). Sydney: ANROWS 
Keiller, Scott W. (2010). Male Narcissism and Attitudes Toward Heterosexual Women and Men, Lesbian Women, and Gay Men: Hostility toward Heterosexual Women Most of All. Sex Roles 63(7-8), 530-541.

Liamputtong, P. And Ezzy, D. (2005). Qualitative research methods. South Melbourne: Oxford University Press.

Macdonald, G., (2016) IPV and Private Family Court Proceedings: Promoting Child Welfare or Promoting Contact? Violence Against Women 22(7) 832

McKinnon, L. (2008). Hurting without hitting: Non-physical contact forms of abuse. Australian Domestic and Family Violence Clearinghouse, UNSW.

Meier, J.S., (2018) Family Court Outcomes Project - Empirical Analysis of Custody Cases Involving Abuse and Alienation, International Society of Family Law, North American Regional Conference, University of Minnesota Law School.

Meier, J.S. (2009) A Historical Perspective on Parental Alienation Syndrome and Parental Alienation Journal of Child Custody,(6) 232

Meier, J.S. (2003). IPV, child custody, and child protection: Understanding judicial resistance and imagining solutions. Washington: The George Washington University Law School.

Midson, B. (2014). The Helpless Protecting the Vulnerable-Defending Coerced Mothers Charged with Failure to Protect. Victoria U. Wellington L. Rev., (45) 297-320.

Moloney, L., Smyth, B., Weston, R., Richardson, N., Qu, L \& Grey, M. (2007). Allegations of family violence and child abuse in family law children's proceedings: A pre-reform exploratory study. Canberra: Australian Institute of Family Studies.

Morgan, M., \& Coombes, L. (2016). Protective mothers: Women's understandings of protecting children in the context of legal interventions into IPV. The Australian Community Psychologist, 28(1), 55-74. 
National Council to Reduce Violence Against Women and their Children. (2009). Background Paper to Time for Action: The National Council's Plan for Australia to Reduce Violence against Women and their Children, 2009-202.

Naughton, C.M., O’Donnell, A.T., Greenwood, R. M \& Muldoon, O.T. (2015). Ordinary decent IPV: A discursive analysis of family law judges' interviews. Discourse and Society, 26, 349-365.

Our Watch, Australia's National Research Organisation for Women's Safety (ANROWS) and VicHealth. (2015). Change the story: A shared framework for the primary prevention of violence against women and their children in Australia. Melbourne, Australia: Our Watch.

Payne, G. \& Williams, M. (2005). Generalisation in Qualitative Research. Sociology, 39(2), 295-314.

Peled, E. (2000). Parenting by men who abuse women: Issues and dilemmas. British Journal of Social Work, 30, 25-36

Pence, E., Davis, G., Beardslee, C \& Gamache, D. (2012). Mind the gap: Accounting for IPV in child custody evaluations. Minneapolis: The Battered Women's Justice Project.

Radford, L \& Hester, M. (2006). Mothering through IPV. London: Jessica Kingsley Publishers. Rathus, Z. (2010). Social science or 'lego-science'? Presumptions, politics, parenting and the new family law. QUT Law Review, 10(2), 164-190.

Rathus, Z., (2013) Shifting Language \& Meanings between Social Science and the Law: Defining Family Violence, University of NSW Law Journal 36(2), 359

Rendell, K., Lynch, A., \& Rathus, Z. (2000). An unacceptable risk: A Report on child contact arrangements where there is violence in the family. Women's Legal Service.

Rowan, D. (1985). 'The Syndrome of Battered Women', National Conference on IPV. Australian Institute of Criminology: Canberra. 
Ryan, G. W., \& Bernard, H. R. (2003). Techniques to identify themes. Field methods, 15(1), 85-109.

Saunders, D.G. and Faller, K.C (2016) The Need to Carefully Screen for IPV When Parental Alienation is Claimed, Michigan Family Law Journal 46(6), 7-11.

Saunders, D. (2007). Child custody and visitation decisions in IPV cases: legal trends, risk factors, and safety Concerns. Applied Research Forum: National Online Resource Center on Violence Against Women. Available at: http://www.vawnet.org/appliedresearch-papers/print-document.php?doc_id $=1134$

Saunders, D.G., Faller, K.C \& Tolman, R.M. (2012). Child custody evaluators' beliefs about domestic abuse allegations: Their relationship to evaluator demographics, background, IPV knowledge and custody-visitation. Washington: United States Department of Justice.

Saunders, D.G., Tolman, R.M. \& Faller, K.C. (2013). Factors associated with child custody evaluators' recommendations in cases of IPV. Journal of Family Psychology, 27(3), 473-483.

Schensul, S., L., Schensul, J., J. \& LeCompte, M., D. (1999). Essential Ethnographic Methods: Observations, Interviews, and Questionnaires. Walnut Creek.

Shea Hart, A. (2006). Children exposed to IPV: Whose 'best interests' in family court. $\mathrm{PhD}$ Thesis, Adelaide: University of South Australia.

Shea Hart, A. (2011). Child safety in Australian family law: Responsibilities and challenges for social science experts in IPV cases. Australian Psychologist, 46, 31-40.

Sifris, A., \& Parker, A. (2014). Family violence and family law: Where to now?. Family Law Review, 3-24.

Smart, C. (1989). Feminism and the Power of Law. London: Routledge. 
Stark, E. (2007). Coercive control: How men entrap women in personal life. Oxford: Oxford University Press.

Stark, E. (2009). Rethinking custody evaluation in cases involving IPV. Journal of Child Custody, 6, (3-4), 287-321.

Strickland, S., and Murray, K., (2014) A Judicial Perspective on the Australian Family Violence Reform 12 Months On. Australian Journal of Family Law 28, 47-82.

Thiara, R. \& Harrison, C. (2016). Safe not sorry: Supporting the campaign for safer child contact: Key issues raised by research on child contact and IPV. Bristol: Women's Aid.

Thiara, R. K., \& Humphreys, C. (2017). Absent presence: the ongoing impact of men's violence on the mother-child relationship. Child \& Family Social Work, 22(1), 137-145.

Thompson, P. (1978). The Voice of the Past: Oral History. Oxford: Oxford University Press.

Thomsen, C., Crouch, J., May, P., Gold, S. and Milner, J. (2005). Predicting Adult Risk of Child Physical Abuse from Childhood Exposure to Violence: Can Interpersonal Schemata Explain the Association. Journal of Social and Clinical Psychology (24) 981

United Nations General Assembly (1993), Declaration on the Elimination of Violence against Women. Available at: http://www.un.org/documents/ga/res/48/a48r104.htm

Walker, L. E. (2016). The battered woman syndrome. Springer publishing company.

Wareham, N., (2015) The Complaints against Family Consultants, at $<$ http://afccnet.org.au/wp-content/uploads/bsk-pdfmanager/10_WORKSHOP_6_HAND_OUT.PDF>

Woffordt, S., Mihalic, D.E., Menard, S. (1994). Continuities in marital violence. Journal of Family Violence, 9, 195-225.

World Health Organization and London School of Hygiene and Tropical Medicine. 2010. Preventing intimate partner and sexual violence against women: Taking action and generating evidence. Geneva, World Health Organization. 
This is an Accepted Manuscript of an article published by Taylor \& Francis Group in Victims and Offenders on 14-03-2019, available online: https://www.tandfonline.com/doi/full/10.1080/15564886.2019.1580646. 